\title{
Secretion of prostaglandins and progesterone by cells from corpora lutea of mares
}

\author{
E. D. Watson and P. L. Sertich \\ Section of Reproductive Studies, University of Pennsylvania School of Veterinary Medicine, \\ New Bolton Center, 382 W. Street Rd, Kennett Square, Pennsylvania 19348, USA
}

Summary. Corpora lutea (CL) were collected from mares during early (Day 4-5), mid(Day 8-9), and late (Day 12-13) dioestrus. Dispersed cell suspensions were obtained by enzymic digestion of tissue. Two distinct luteal cell populations (large and small) were observed. The proportion of small luteal cells significantly increased as age of CL advanced.

Cells $\left(2 \times 10^{6}\right)$ from $C L$ which were incubated for 24 h secreted prostaglandin $(P G)$ F, PGE-2 and 6-keto-PGF-1 $\alpha$ (the stable metabolite of prostacyclin). Higher concentrations of all PGs were produced by cells from $\mathrm{CL}$ at early dioestrus than from those at mid- or late dioestrus. The ratio of PGF:PGE- 2 increased from 0.33 in CL of early dioestrus to 1.34 in $C L$ of mid-dioestrus, whereas ratios of PGF:6-keto-PGF- $1 \alpha$ remained relatively constant $(\sim 0 \cdot 6)$. The ratio of PGE-2:6-keto-PGF-1 $\alpha$ from $C L$ decreased between early (3.27) and mid-dioestrus (0.43). Addition of LH, dbcAMP, or ionophore to cell cultures did not consistently affect secretion of progesterone or PGs by luteal cells. It is suggested that prostaglandins produced by luteal cells of mares may contribute to control of luteal function and that the changing ratios of prostaglandins may be more important in controlling the lifespan of the $\mathrm{CL}$ than absolute concentrations of each.

Keywords: mare; corpus luteum; prostaglandins; progesterone

\section{Introduction}

In domestic species, prostaglandins (PGs) have both luteolytic (Douglas \& Ginther, 1972; Fitz et al., 1984a) and luteotrophic (Huecksteadt \& Weems, 1978; Milvae \& Hansel, 1983) roles. In the mare, unlike other species, the luteolytic effect of uterine PGF-2 $\alpha$ apparently is not exerted via a local vascular pathway from the uterus (Ginther, 1974). Prostaglandin F-2 $\alpha$ tends to have a very short half-life (seconds) once it enters the systemic circulation, and so only minute concentrations of uterine PGF-2 $\alpha$ can reach the ovary. It is thought that the corpus luteum $(\mathrm{CL})$ of the mare partly compensates by exhibiting an increased binding affinity for PGF-2 $\alpha$ (F. A. Kimball, personal communication) compared with other species. However, it is also possible that tissues other than the uterus may contribute to PGF- $2 \alpha$ synthesis at luteolysis. In cattle and primates it has been shown that luteal cells themselves secrete PGs (Patwardhan \& Lanthier, 1980; Milvae \& Hansel, 1983; Rodgers et al., 1988). These studies suggest that local PGF may contribute to the regulation of luteolysis. Other PGs may also be produced by luteal cells which could influence the lifespan of the CL. PGE-2 and prostacyclin have been shown to be luteotrophic in other species (Huecksteadt \& Weems, 1978; Milvae \& Hansel, 1983), but their effect on luteal cells of mares is not known.

There is no information regarding local production of PGs by ovarian tissue in the mare or whether these PGs could influence the lifespan of the CL. The present study measured production of PGF, PGE-2, 6-keto-PGF-1 $\alpha$ (the stable metabolite of prostacyclin) and progesterone by dispersed equine luteal cells in culture. The effects of substances known in other species to affect 
secretion of progesterone and PGs by luteal cells, e.g. indomethacin, luteinizing hormone (LH), calcium ionophore, and dibutyryl cyclic AMP (dbc AMP), were also evaluated.

\title{
Materials and Methods
}

\begin{abstract}
Animals. Six horse mares (Thoroughbred and Standardbred) from 3 to 12 years of age were used. Throughout the spring and summer, all mares exhibited normal patterns of oestrous behaviour and ovulation. During the oestrous period under study, the mares' ovaries were examined daily by ultrasonography per rectum to determine day of ovulation, which was designated Day 0 . The ovary containing the CL was removed at Day 4 or 5 , Day 8 or 9 , or Day 12 or 13 after ovulation. The remaining ovary was similarly removed at one of these time intervals after the next ovulation.
\end{abstract}

Surgery. Ovaries were removed using an ecraseur via an incision in the cranial vagina. Sedation and analgesia were achieved with intravenous administration of xylazine and butorphanol. Anaesthesia of the ovarian ligament was attained by local application of lignocaine before applying the ecraseur.

Preparation of luteal cells. After excision, ovaries were placed in Medium 199 (Gibco Laboratories, Grand Island, NY, USA) on ice and transported to the laboratory. The CL was dissected from the ovary and the capsule was removed. The tissue was then minced and weighed. Dispersed cell suspensions were prepared by collagenase digestion: $5 \mathrm{~g}$ luteal tissue were added to $10 \mathrm{ml}$ Hanks balanced salt solution (calcium- and magnesium-free; Gibco Laboratories) supplemented with $7.6 \mathrm{mg}$ collagenase, $2 \mathrm{mg}$ deoxyribonuclease, $20 \mathrm{~mm}$-Hepes buffer, 500 units penicillin, $500 \mu \mathrm{g}$ streptomycin, and $1 \%$ bovine serum albumin. All additives were purchased from Sigma Chemical Company (St Louis, MO, USA). Dissociation of cells was achieved by incubation for $45 \mathrm{~min}$ at $37^{\circ} \mathrm{C}$ in a shaking water bath. The mixture was then centrifuged for $10 \mathrm{~min}$ at $125 \mathrm{~g}$. The supernatant was discarded and the incubation repeated with fresh medium containing collagenase for a further $45 \mathrm{~min}$. After further centrifugation, the cells were resuspended in a small volume of Medium 199. Clumps of cells were dispersed by repeated gentle aspiration into a sterile syringe. After straining the mixture through a gauze filter, the cells were washed twice in Medium 199 and then resuspended in culture medium (Medium 199 containing 50 units penicillin, $50 \mu \mathrm{g}$ streptomycin, $10 \%$ heat-inactivated newborn calf serum, and $4.7 \mathrm{H} 7.5 \%$ bicarbonate per $\mathrm{ml}$ ). By this stage, single cell suspensions were obtained apart from a few of the small luteal cells which tended to remain in small sheets of tissue. Similar degrees of dissociation were obtained for tissue from mares at all stages of dioestrus. Luteal cells were counted using a haemocytometer and suspended in medium at $5 \times 10^{5} / \mathrm{ml}$. A smear of each cell suspension was prepared for histological examination using a cytocentrifuge and stained with Diff-Quik (Baxter Scientific, McGraw Park, IL, USA) to differentiate cells.

Luteal cell incubations. Incubations were performed at $37^{\circ} \mathrm{C}$ in a humidified atmosphere of $5 \% \mathrm{CO}_{2}: 95 \%$ air. Luteal cells $(4 \mathrm{ml})$ were added to $60-\mathrm{mm}$ sterile plastic tissue culture dishes (Becton Dickinson, Lincoln Park, NJ, USA) and incubated for $24 \mathrm{~h}$. After incubation, the suspensions were centrifuged at $2000 \mathrm{~g}$ for $10 \mathrm{~min}$ to pellet nonadherent luteal cells and the supernatant was stored at $-20^{\circ} \mathrm{C}$ until assay. To check whether progesterone was being synthesized by cells in culture rather than being passively released, $1 \mathrm{ml}$ cells from each of 5 CL were frozen before incubation as well as after a 2-h incubation. The cells were lysed by freezing and thawing and cell contents and medium were assayed.

Treatments. The following treatments were applied in a volume of $0.1 \mathrm{ml}$ to triplicate culture dishes. Concentrations quoted are the final concentrations in medium: $\operatorname{dbcAMP}(1 \mathrm{mmol} / \mathrm{l} ;$ Sigma Chemical Co. $)$, calcium ionophore $(40 \mu \mathrm{g} / \mathrm{ml}$; Calbiochem, San Diego, CA, USA), indomethacin $(4 \mu \mathrm{g} / \mathrm{ml}$; Sigma Chemical Co.), and horse LH (100 ng/ml).

Progesterone assay. The assay has been described previously (Watson \& Hinrichs, 1988). The assay was performed directly in centrifuged culture supernatant without extraction. The samples containing cells (the 0 and $2-\mathrm{h}$ cultures) were extracted twice in petroleum ether before assay. Recovery of progesterone after extraction was $95 \%$. The main cross-reactivities $(>1.0 \%)$ of the antiserum were with progesterone $100 \%, 11$-deoxycorticosterone $1.7 \%, 11$ -

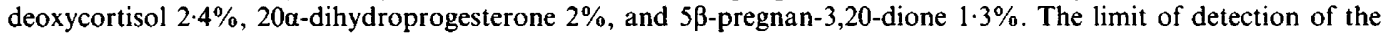
assay was $25 \mathrm{pg} / \mathrm{ml}$. Within- and between-assay coefficients of variation were $6 \%$ and $9 \%$, respectively.

PGF assay. Concentrations were measured directly in culture medium. The method has been described previously (Watson et al., 1987). The main cross-reactivities (>1.0\%) of the antiserum were PGF-2 $\alpha 100 \%$, PGF-1 $\alpha 75 \%$, and PGF- $2 \beta 1.5 \%$. Standard curves prepared in assay buffer and culture medium were parallel. Recovery of PGF was $102 \pm 6.8 \%$ (mean \pm s.d.). The coefficient of correlation of added:recovered PG was 0.99 . Limit of detection of the assay was $0.25 \mathrm{ng} / \mathrm{ml}$. Within-assay coefficient of variation was $6 \%$. All samples were included in one assay.

PGE-2 assay. Reagents were purchased from New England Nuclear (North Billerica, MA, USA). An iodinated tracer was used. Samples were assayed directly without extraction at a dilution of 1:10. Main cross-reactivities $(>1.0 \%)$ of the antibody were with PGE-2 $100 \%$ and PGE-1 $3.7 \%$. Standard curves prepared in assay buffer and culture medium were parallel, with a coefficient of correlation of 0.99 between added and recovered PGE- 2 . Recovery of PGE-2 was $102 \pm 8 \cdot 2 \%$ (mean \pm s.d.). The limit of detection of the assay was $2.5 \mathrm{pg} / \mathrm{ml}$. Within-assay coefficient of variation was $3 \%$ and all samples were included in one assay. 
6-Keto-PGF-1a assay. Reagents were purchased from New England Nuclear. Samples were assayed directly at a dilution of 1:10. Major cross-reactivities (>1.0\%) of the antibody were with 6-keto-PGF-1 $\alpha 100 \%$, PGF- $2 \alpha 2 \cdot 6 \%$, PGE-1 $1.9 \%$, TXB-2 $1.4 \%$ and PGE-2 $1.1 \%$. Standard curves prepared in assay buffer and culture medium were parallel. The correlation coefficient for added:recovered 6-keto-PGF-1 $\alpha$ was 0.99 . The limit of detection of the assay was $20 \mathrm{pg} / \mathrm{ml}$. Recovery of 6-keto-PGF-l $\alpha$ was $85 \pm 15 \cdot 1 \%$ (mean \pm s.d.). Within-assay coefficient of variation was $4 \cdot 3 \%$. All samples were performed in the same assay.

Statistical analysis. Differences in hormone concentrations or in luteal cell numbers were analysed using analysis of variance. Correlations were tested using Pearson's test. Levels of significance of $P<0.05$ were considered significant.

\section{Results}

CL collected during early, mid- or late dioestrus were similar in weight (Table 1). The number of cells isolated from these CL did not vary significantly. Isolated cells consisted mainly of three distinct cell types: (1) large luteal cells $(20-65 \mu \mathrm{m}$; mean \pm s.e.m. $42 \pm 1.8 \mu \mathrm{m})$ which were large, polyhedral cells with vacuolated cytoplasm and a single round or oval eccentric pale nucleus containing one or more nucleoli; (2) small luteal cells $(7-18 \mu \mathrm{m} ; 11 \cdot 1 \pm 0.4 \mu \mathrm{m})$ which were smaller, often elongated with irregular dark-staining nuclei; and (3) a few spindle-shaped endothelial cells. Moderate contamination with red blood cells was common as were small numbers of leucocytes. The proportion of large luteal cells decreased significantly between mid- and late dioestrus (Table 1), but actual numbers did not change significantly $\left(2 \cdot 1 \times 10^{7}\right.$ in mid-dioestrus; $6.0 \times 10^{7}$ in late dioestrus $)$.

Table 1. Weights, cell numbers and ratio of large to small cells isolated from $\mathrm{CL}$ of mares

\begin{tabular}{lccc}
\hline & \multicolumn{3}{c}{ Age of corpora lutea } \\
\cline { 2 - 4 } & $4-5$ days & $8-9$ days & $12-13$ days \\
\hline No. of mares & 4 & 4 & 4 \\
Weight of CL $(\mathrm{g})$ & $6 \cdot 7 \pm 0 \cdot 6$ & $5 \cdot 6 \pm 0 \cdot 2$ & $5 \cdot 5 \pm 1 \cdot 0$ \\
No. of luteal cells per CL $\left(\times 10^{-7}\right)$ & $5 \cdot 7 \pm 1 \cdot 5$ & $5 \cdot 5 \pm 2 \cdot 0$ & $24 \cdot 5 \pm 12 \cdot 7$ \\
No. of large:small luteal cells $(\%)$ & $46 \pm 4 \cdot 7^{\mathrm{a}}$ & $38 \cdot 5 \pm 0.9^{\mathrm{b}}$ & $24 \cdot 3 \pm 2 \cdot 0^{\mathrm{a} . \mathrm{b}}$ \\
\hline
\end{tabular}

Values are mean \pm s.e.m.

Values with similar superscripts differ significantly: a, $P<0.01$; b, $P<0.001$.

Over a 2-h incubation period, there was a $53 \pm 3.9 \%$ (s.e.m.) increase in progesterone content of cells plus medium. By $24 \mathrm{~h}$, there was a 2-4-fold increase in progesterone concentrations compared with concentrations at $2 \mathrm{~h}$. In one experiment, plating efficiency of cells was $71 \%$ as determined by counting cells present in culture medium aspirated after $24 \mathrm{~h}$. Before plating, $80 \%$ of cells were viable (judged by trypan blue exclusion). After $24 \mathrm{~h}, 77 \%$ of the cells which had not adhered to the plate were viable.

Over a 24-h incubation period, progesterone production by cells did not vary significantly with stage of cycle (532 $\pm 252 \mathrm{ng}$ on Day $4-5 ; 1124 \pm 307 \mathrm{ng}$ on Day 8-9; $258 \pm 76 \cdot 2 \mathrm{ng}$ on Day 12-13) or after addition of $\mathrm{LH}$, indomethacin, dbcAMP or calcium ionophore (data not shown).

Luteal cells from $\mathrm{CL}$ collected early in dioestrus produced significantly more PGs $(P<0 \cdot 01)$ than did cells from mid-dioestrus CL and more PGF $(P<0.01)$, PGE-2 $(P<0.01)$, and 6-ketoPGF-1 $\alpha(P<0.05)$ than did cells from late CL (Fig. 1). There were no significant differences between concentrations of PGF and 6-keto-PGF-1 $\alpha$ produced by luteal cells collected in mid- or late dioestrus, but PGE-2 increased significantly $(P<0.05)$ between mid- and late dioestrus. There were significant $(P<0.01)$ positive correlations between concentrations of the PGs produced by luteal cells. Cultures to which indomethacin was added generally contained lower concentrations of PGs than did control cultures. Luteal cells from CL at mid-dioestrus tended to synthesize little 
PGF, and there was no significant difference in PGE-2 concentrations in cultures with and without indomethacin. Neither LH nor dbcAMP significantly affected PG production, but ionophore decreased release of PGE-2 and 6-keto-PGF-1 $\alpha$ from early CL.

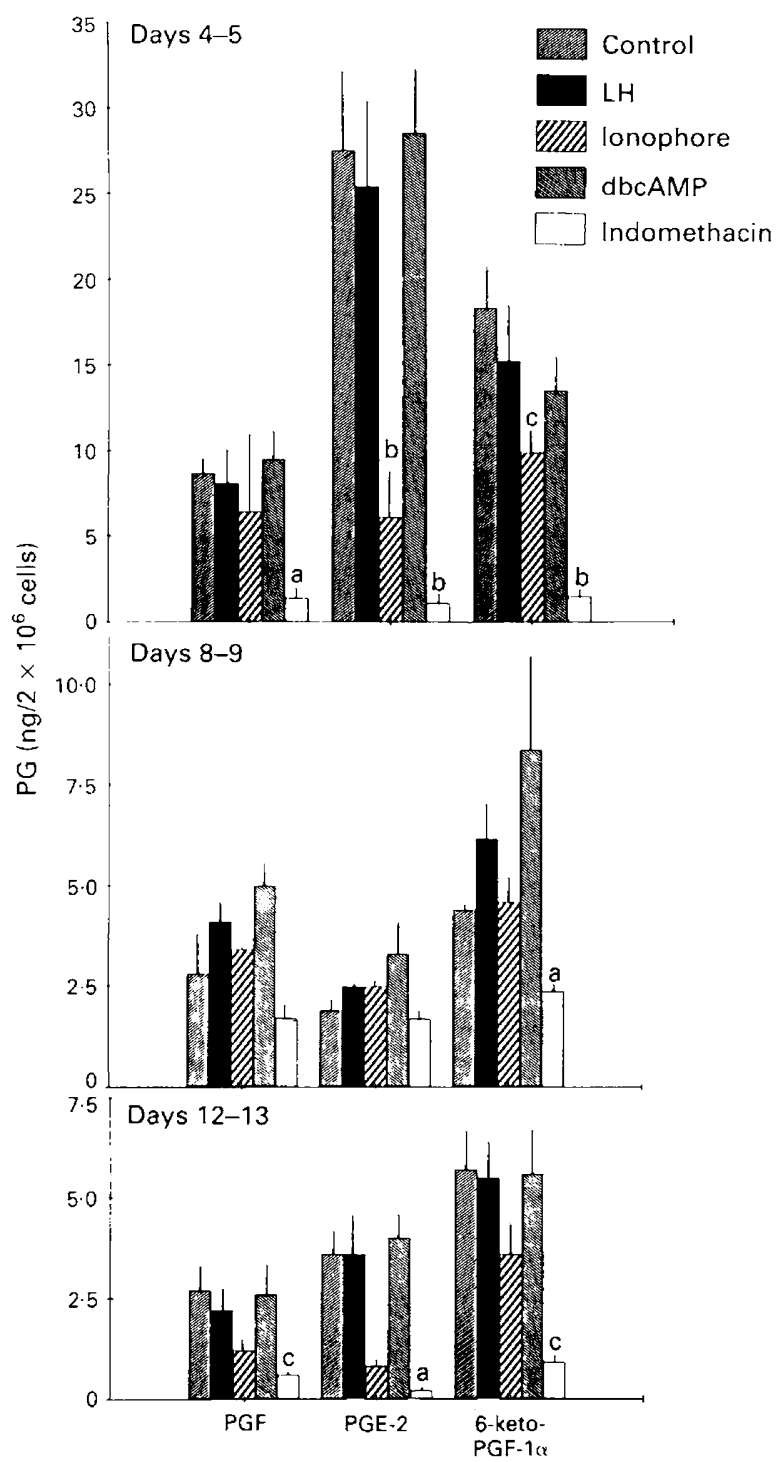

Fig. 1. Release of prostaglandins from luteal cells of mares during early, mid-and late dioestrus after treatment with LH $(100 \mathrm{ng} / \mathrm{ml})$, ionophore $(40 \mu \mathrm{g} / \mathrm{ml})$, dbcAMP $(1 \mathrm{mmol} / \mathrm{l})$ or indomethacin $(4 \mu \mathrm{g} / \mathrm{ml})$. Values are mean \pm s.e.m. for $4 \mathrm{CL}$ per stage of cycle. Values differing significantly from controls: a, $P<0.001 ; \mathrm{b}, P<0.01 ; \mathrm{c}, P<0.05$.

The ratio of PGF:PGE-2 released by luteal cells increased as the cycle advanced (Table 2). By contrast, the ratio of PGF to 6-keto-PGF-1 $\alpha$ remained relatively constant in cultures of luteal cells collected from early through late dioestrus. The ratio of PGE-2:6-keto-PGF-1 $\alpha$ released by luteal cells decreased between early and mid- and late dioestrus. 
Table 2. Ratios (mean \pm s.e.m.) of prostaglandins released by luteal cells of mares during a $24-\mathrm{h}$ incubation period

\begin{tabular}{llll}
\hline & \multicolumn{3}{c}{ Age of corpora lutea } \\
\cline { 2 - 4 } & \multicolumn{1}{c}{$4-5$ days } & $8-9$ days & $12-13$ days \\
\hline PGF:PGE-2 & $0.33 \pm 0.04^{\mathrm{a}, \mathrm{b}}$ & $1 \cdot 34 \pm 0.24^{\mathrm{a}}$ & $0.74 \pm 0 \cdot 18^{\mathrm{b}}$ \\
PGF:6-keto-PGF-1 $\alpha$ & $0.52 \pm 0.68$ & $0.61 \pm 0.18$ & $0.72 \pm 0.31$ \\
PGE-2:6-keto-PGF-1 $\alpha$ & $3.27 \pm 1 \cdot 18^{\mathrm{c}, \mathrm{d}}$ & $0.43 \pm 0.05^{\mathrm{c}}$ & $0.82 \pm 0.26^{\mathrm{d}}$ \\
\hline
\end{tabular}

For differences between cycle stage: a, $P<0.001$; b, $P<0.05$;,$P<0.01$;,$P<0.05$.

\section{Discussion}

In this study, luteal cells from the CL of mares in early, mid- and late dioestrus released PGs, and concentrations decreased as the age of the CL increased. A similar pattern of PG release has been reported using luteal cells collected from cattle at different stages of dioestrus (Rodgers et al., 1988), but in the horse, PGE-2 tended to be the predominant PG released by the early CL rather than 6-keto-PGF-1 $\alpha$. Addition of indomethacin (a known inhibitor of prostaglandin synthesis) to cultures lowered concentrations of PGs in culture medium, indicating that PGs were actively being synthesized by the luteal cells during incubation. Red blood cells reportedly do not secrete PGs (Higgs, 1982). Therefore, the contaminating red blood cells in luteal cell cultures probably did not contribute to concentrations of PGs measured in medium. High concentrations of PGE-2 and 6-keto-PGF-1 $\alpha$ were released by luteal cells early in the cycle. In the cow, it is thought that prostacyclin may be luteotrophic early in the development of the $\mathrm{CL}$ specifically by controlling proliferation of blood vessels (Milvae \& Hansel, 1983). The decreased synthesis of PGF by cells cultured from late $\mathrm{CL}$ of mares suggests that locally produced PGF is not primarily responsible for luteolysis in this species. However, the ratio of PGF:PGE-2 released by luteal cells during culture increased as the cycle advanced. In other species, PGE-2 is thought to be luteotrophic (Huecksteadt \& Weems, 1978; Fitz et al., 1984b) and it has been postulated that an increase in the ratio of luteolytic to luteotrophic concentrations of PGs during the later stages of the cycle rather than concentrations of individual PGs may be of significance in luteolysis (Balmaceda et al., 1979; Patwardhan \& Lanthier, 1980; Milvae \& Hansel, 1983; Rodgers et al., 1988). It is possible that a similar mechanism operates in the mare. However, administration of PGE to cyclic mares did not prolong the lifespan of the CL (see Sharp et al., 1989).

Both calcium ionophore and dbcAMP stimulate PG synthesis by luteal cells of other species (Johnson et al., 1988; Rodgers et al., 1988). In the present study, neither was stimulatory when added to horse luteal cells, and inophore frequently tended to decrease PG synthesis.

Horse LH has been shown to increase production of progesterone by luteal cells of mares (Kelly et al., 1988b), and in other species dbcAMP acted like LH in stimulating progesterone production by cultured luteal cells (Godkin et al., 1977; O'Shaughnessey \& Wathes, 1985). In our study, progesterone production by horse luteal cells was not stimulated by ionophore, dbcAMP or LH (data not shown). It is possible that differences between the present and previous studies may be a function of the culture conditions. For example, it has been shown that LH does not stimulate progesterone production by sheep and cattle luteal cells when they are cultured in a medium containing serum (Pate $\&$ Condon, 1982; Hoyer et al., 1988). We suggest that the presence of LH in the serum may already be maximally stimulating the luteal cells. Alternatively, numbers of $\mathrm{LH}$ receptors could be decreased during culture under certain conditions.

In the present study, addition of indomethacin to luteal cell cultures did not affect progesterone production, showing that PGs did not influence progesterone synthesis under these culture conditions. Similar results have been reported for luteal cells of cattle (Milvae \& Hansel, 1983; Pate \& Condon, 1984). 
In the present study, cells were not stained for $3 \beta$-hydroxysteroid dehydrogenase activity and, therefore, the number of steroidogenic cells is not known. More than $80 \%$ of luteal cells isolated from mid-cycle sheep CL are non-steroidogenic (Fitz et al., 1982). In the present study, the increase in progesterone concentrations measured in cells plus medium $2 \mathrm{~h}$ after the start of incubation, compared with before incubation, shows that progesterone was being synthesized by the luteal cells. No significant differences in progesterone production by luteal cells were detected at different stages of the cycle, although concentrations tended to decrease later in the cycle.

It is likely that the numbers of luteal cells harvested by dispersion are considerably lower than the actual cell content of the CL. Work performed with sheep and cow CL has shown that cell dissociation results in loss of cells with possibly selective loss of certain cell types (Rodgers et al., 1984; O'Shea et al., 1989). The ratio of small to large luteal cells reported in this study agrees, however, with morphometric studies on mare luteal tissue (Van Niekerk et al., 1975), and the proportion of small to large luteal cells increased as the cycle progressed. In other species, the two populations of luteal cells have distinct functional properties with regard to progesterone synthesis and sensitivity to LH and PGs (Koos \& Hansel, 1981; Fitz et al., 1982, 1984a, b; O'Shea, 1987; Alila et al., 1988a, b). In other species, the proportion of small to large luteal cells decreases as the cycle advances (Fitz et al., 1981; Niswender et al., 1985) and it is thought that these cell changes facilitate control of the lifespan of the CL, i.e. increased numbers of large cells in late dioestrus which bear the majority of the receptors for PGF-2 $\alpha$, thereby increasing the sensitivity of the CL to the action of PGF-2 $\alpha$. There is no information regarding functional properties of small and large luteal cells in the mare.

We thank Nancy Diehl for excellent assistance; Dr Hans Kindahl (Uppsala) for PGF antiserum; Dr Harold Papkoff, California, for purified horse LH; and Dr Ellen Ziemer for help with differentiation of cell types. This study was financed by a grant from Friends of New Bolton Center.

\section{References}

Alila, H.W., Corradino, R.A. \& Hansel, W. (1988a) A comparison of the effects of cyclooxygenase prostanoids on progesterone production by small and large bovine luteal cells. Prostaglandins 36, 259-270.

Alila, H.W., Dowd, J.P., Corradino, R.A., Harris, W.V. \& Hansel, W. (1988b) Control of progesterone production in small and large bovine luteal cells separated by flow cytometry. J. Reprod. Fert. 82, 645-655.

Balmaceda, J., Asch, R.H., Fernandez, E.O., Valenzuela, G., Eddy, C.A. \& Pauerstein, C.J. (1979) Prostaglandin production by Rhesus monkey corpora lutea in vitro. Fert. Steril. 31, 214-216.

Douglas, R.H. \& Ginther, O.J. (1972) Effect of prostaglandin $\mathbf{F}-2 \alpha$ on length of diestrus in mares. Prostaglandins 2, 265-268.

Fitz, T.A., Sawyer, H.R. \& Niswender, G.D. (1981) Characterization of two steroidogenic cell types in the ovine corpus luteum. Biol. Reprod. 24 (Suppl 1), $54 \mathrm{~A}$, abstr.

Fitz, T.A., Mayan, M.H., Sawyer, H.R. \& Niswender, G.D. (1982) Characterization of two steroidogenic cell types in the ovine corpus luteum. Biol. Reprod. 27, 703-711.

Fitz, T.A., Mock, E.J., Mayan, M.H. \& Niswender, G.D. (1984a) Interactions of prostaglandins with subpopulations of ovine luteal cells. II. Inhibitory effects of PGF- $2 \alpha$ and protection by PGE-1. Prostaglandins 28, 127-138.

Fitz, T.A., Hoyer, P.B. \& Niswender, G.D. (1984b)
Interactions of prostaglandins with sub-populations of ovine luteal cells. I. Stimulatory effects of prostaglandins E-1, E-2 and I-2. Prostaglandins 28, $119-126$.

Ginther, O.J. (1974) Internal regulation of physiological processes through local veno-arterial pathways: a review. J. Anim. Sci. 39, $550-564$.

Godkin, J.D., Black, D.L. \& Duby, R.T. (1977) Stimulation of cyclic AMP and progesterone synthesis by LH, PGE-2 and isoproterenol in the bovine $\mathrm{CL}$ in vitro. Biol. Reprod. 17, 514-518.

Higgs, G.A. (1982) Arachidonic acid metabolism in leukocytes. In Phagocytosis-Past and Future, pp. 105-129. Eds M. L. Karnovsky \& L. Bolis. Academic Press, London.

Hoyer, P.B., Kong, W., Crichton, E.G., Bevan, L. \& Krutzsch, P.H. (1988) Steroidogenic capacity and ultrastructural morphology of cultured ovine luteal cells. Biol. Reprod. 38, 909-920.

Huecksteadt, T.P.\& Weems, C.W. (1978) Effect of PGE-1 on normal luteolysis and PGE-1 or PGE-2 on IUD-induced luteolysis in ewes. Pharmacologist 20, 233-234.

Johnson, M.S., Ottobre, A.C. \& Ottobre, J.S. (1988) Prostaglandin production by corpora lutea of Rhesus monkeys: characterization of incubation conditions and examination of putative regulators. Biol. Reprod. 39, 839-846.

Kelly, C.M., Hoyer, P.B. \& Wise, M.E. (1988) In-vitro and in-vivo responsiveness of the corpus luteum of 
the mare to gonadotrophin stimulation. J. Reprod. Fert. 84, 593-600.

Koos, R.D. \& Hansel, W. (1981) The large and small cells of the bovine corpus luteum: Ultrastructural and functional differences. In Dynamics of Ovarian Function, pp. 197-203. Eds N. B. Schwartz \& M. Hunzicker-Dunn. Raven Press, New York.

Milvae, R.A. \& Hansel, W. (1983) Prostacyclin, prostaglandin F-2 $\alpha$ and progesterone production by bovine luteal cells during the estrous cycle. Biol. Reprod. 29, 1063-1068.

Niswender, G.D., Schwall, R.H., Fitz, T.A., Farin, C.E. \& Sawyer, H.R. (1985) Regulation of luteal function in domestic ruminants: New concepts. Recent Prog. Horm. Res. 41, 101-151.

O'Shaughnessy, P.J. \& Wathes, D.C. (1985) Characteristics of bovine luteal cells in culture: morphology, proliferation and progesterone secretion in different media and effects of $\mathbf{L H}$, dibutyryl cyclic AMP, antioxidants and insulin. J. Endocr. 104, 355-361.

O'Shea, J.D. (1987) Heterogeneous cell types in the corpus luteum of sheep, goats and cattle. J. Reprod. Fert. 34, 71-85.

O'Shea, J.D., Rodgers, R.J. \& D’Occhio, M.J. (1989) Cellular composition of the cyclic corpus luteum of the cow. J. Reprod. Fert. 85, 483-487.

Pate, J.L. \& Condon, W.A. (1982) Effects of serum and lipoproteins on steroidogenesis in cultured bovine luteal cells. Molec. cell. Endocr. 28, 551-562.

Pate, J.L. \& Condon, W.A. (1984) Effects of prostaglandin $\mathrm{F}-2 \alpha$ on agonist-induced progesterone production in cultured bovine luteal cells. Biol. Reprod. 31, 427-435.

Patwardhan, V.V. \& Lanthier, A. (1980) Concentration of prostaglandins PGE and PGF, estrone, estradiol and progesterone in human corpora lutea. Prostaglandins 20, 963-969.

Rodgers, R.J., O'Shea, J.D. \& Bruce, N.W. (1984) Morphometric analysis of the cellular composition of the ovine corpus luteum. J. Anat. 138, 757-769.

Rodgers, R.J., Mitchell, M.D. \& Simpson, E.R. (1988) Secretion of progesterone and prostaglandins by cells of bovine corpora lutea from three stages of the luteal phase. J. Endocr. 118, 121-126.

Sharp, D.C., McDowell, K.J., Weithenauer, J. \& Thatcher, W.W. (1989) The continuum of events leading to maternal recognition of pregnancy in mares. J. Reprod. Fert., Suppl. 37, 101-107.

Van Niekerk, C.H., Morgenthal, J.C. \& Gerneke, W.H. (1975) Relationship between the morphology of and progesterone production by the corpus luteum of the mare. J. Reprod. Fert., Suppl. 23, 171-175.

Watson, E.D. \& Hinrichs, K. (1988) Changes in the concentrations of steroids and prostaglandin $F$ in preovulatory follicles of the mare after administration of hCG. J. Reprod. Fert. 84, 557-561.

Watson, E.D., Stokes, C.R., David, J.S.E., Bourne, F.J. \& Ricketts, S.W. (1987) Concentrations of uterine luminal prostaglandins in mares with acute and persistent endometritis. Equine vet. J. 19, 31-37.

Received 25 April 1989 